\title{
Sectioning of radiolarians under continuous observation
}

\author{
Joachim Stanek ${ }^{1}$ \& Wolfgang Kiessling ${ }^{2}$
}

With 7 figures and 1 table

\begin{abstract}
A new method to study the internal structure of fossil radiolarians in presented. The core of the method is (1) freezing the radiolarian in a drop of water using a Peltier module and (2) slicing the radiolarian with a specially equipped electric toothbrush under an optical microscope. With this method the internal structure of diagenetically altered radiolarians can be studied even if internal sediment cannot be removed.
\end{abstract}

Key words: Radiolarians, taxonomy, methodology, internal structures.

\section{Zusammenfassung}

Eine neue Methode zur Analyse der Internstrukturen von Radiolarien wird vorgestellt. Die Methode beinhaltet (1) Einfrieren einzelner Radiolarien in einem Wassertropfen mit Hilfe eine Peltier-Elements und (2) Schleifen der Radiolarien mit Hilfe eine modifizierten elektrischen Zahnbürste unter einem Binokular. Mit dieser Methode ist es möglich Internstrukturen von Radiolarien zu untersuchen, selbst wenn diese diagenetisch verändert sind oder fest verbackenes Internsediment aufweisen.

Schlüsselwörter: Radiolarien, Taxonomie, Methodik, Internstrukturen.

\section{Introduction}

The taxonomic relationships of radiolarians are often obscured if internal structures are not precisely known. Examples are Paleozoic and Mesozoic entactinarians (Kozur \& Mostler 1982, Won 1997, Dumitrica \& Carter 1999), many Mesozoic-Cenozoic spumellarian families (Baumgartner 1980, Dumitrica 1983, Dumitrica 1985, 1988, 1991, 1994) and nassellarians (Takemura 1986). Traditional methods to study the internal structure of radiolarians involve the preparation of smear slides and microslides of sieved samples (e.g., Lazarus 1994). This method produces sufficient results if diagenesis is moderate (Opal-A or Opal-CT preservation) and no internal sediments obscure the internal structures. If the skeletal opal, however, has been transformed to microquartz or abundant fine-grained sediment has accumulated and cemented inside the tests, internal test structures are not commonly recognized in microslides. Thin section preparation of indivi- dual tests (Dumitrica in De Wever et al. 2001) and confocal microscopy (O'Connor 1996) have been used to overcome preservational and optical problems, but are not widely applied due to the complicated procedure and the required technical experience. Here we propose a new method to study the internal structure of individual radiolarians in three dimensions with comparatively little effort. In contrast to similar methods of slicing radiolarians (De Wever et al. 2001: 436-439), our method does not require a lot of experience.

\section{Method}

Our method for the sectioning of radiolarians consists of three steps: (1) Isolation of single radiolarian specimens, (2) snap-freezing of radiolarians in a droplet of water, and (3) sectioning of radiolarians under continuous observation.

\footnotetext{
1 Am Moosrangen 28, D-90614 Ammerndorf, Germany.

2 Institut für Paläontologie, HU Berlin, Invalidenstr. 43, D-10115 Berlin, Germany.

Received March, accepted May 2002
} 
Table 1

Non-standard material and devices used for the radiolarian sectioning

\begin{tabular}{|c|c|c|}
\hline Material & Specifications, purpose & Source, order information \\
\hline Peltier module & $\begin{array}{l}1.9 \mathrm{~V}, 3 \mathrm{~A}, 3.9 \mathrm{~W} \\
\text { Max. } \Delta \mathrm{T}: 60^{\circ} \mathrm{C} \\
\text { Size: } 15 \times 15 \times 4.9 \mathrm{~mm}\end{array}$ & $\begin{array}{l}\text { TEC 1-1703 } \\
\text { www.conrad.com } \\
\text { (Order number 193550-22) }\end{array}$ \\
\hline DC power supply & $\begin{array}{l}\text { Input voltage } 230 \mathrm{~V} \sim / 50 \mathrm{~Hz} \\
\text { Output voltage } 0-30 \mathrm{~V} \mathrm{DC} \\
\text { continuously variable Output current } \\
0-3 \text { A continuously variable }\end{array}$ & $\begin{array}{l}\text { PS 303-A Power Supply } \\
\text { www.conrad.com } \\
\text { (Order number } 511420-22 \text { ) }\end{array}$ \\
\hline Cushioned abrasive & $\begin{array}{l}\text { Cotton flannel sheet with floating } \\
\text { abrasive crystals ( } 1500 \text { to } 6000 \text { grade) } \\
\text { - for radiolarians }\end{array}$ & $\begin{array}{l}\text { Micro Mesh KR } 70 \text { kit } \\
\text { http://pages.restorersupplies.com/5943/Inve } \\
\text { ntoryPage/1316051/1.html or } \\
\text { http://www.micro-surface.com/ }\end{array}$ \\
\hline Flexible diamond hand laps & $\begin{array}{l}\text { Diamond grinding surface for larger } \\
\text { objects (e.g., foraminifers) }\end{array}$ & $\begin{array}{l}\text { DIAPAD 3M kit } \\
\text { http://www.labenson.com/flexdiam.html }\end{array}$ \\
\hline Heat-conducting paste & $\begin{array}{l}\text { Heat conductivity: } 0.61 \mathrm{~W} / \mathrm{mK} \\
\text { Operating temperature range: }-70^{\circ}-250^{\circ} \mathrm{C}\end{array}$ & www.conrad.com (Order number 189154-22) \\
\hline $\begin{array}{l}\text { Electric toothbrush with } \\
\text { rechargeable batteries }\end{array}$ & $\begin{array}{l}\text { Oscillating motion of brush head } \\
\text { required }\end{array}$ & $\begin{array}{l}\text { Colgate or Braun. Available in any } \\
\text { drug store. }\end{array}$ \\
\hline Black self-adhesive foil & $\begin{array}{l}\text { Black background mounted on cooling } \\
\text { device to enhance contrast of target }\end{array}$ & $\begin{array}{l}\text { http://www.aslan-schwarz.com/ } \\
\text { or any office store }\end{array}$ \\
\hline Mesh Nylon & $\begin{array}{l}30-500 \mu \mathrm{m} \text { mesh sizes for sieving } \\
\text { radiolarians }\end{array}$ & $\begin{array}{l}\text { http://www.spectrapor.com/labware/nylon } \\
\text { mesh.htlm }\end{array}$ \\
\hline Copper plate & ca. $10 \times 10 \mathrm{~cm}$ diameter, $3-6 \mathrm{~mm}$ thick & Any hardware seller \\
\hline Ultrasonic device & Cleaning frequency $40 \mathrm{kHz}$ & www.conrad.com (Order number 821080-92) \\
\hline
\end{tabular}

Our method is described using easily accessible and affordable material (Table 1).

1) The isolation of radiolarians involves the extraction from host rocks and picking. The method of isolation from host rocks depends on the lithology. Marls and shales are usually treated with hydrogen peroxide $\left(\mathrm{H}_{2} \mathrm{O}_{2}\right)$, whereas limestones require $\mathrm{HCl}$ treatment, and $\mathrm{HF}$ processing is necessary for cherts. The best results are usually achieved with $10 \% \mathrm{HCl}$ for limestones and $4 \% \mathrm{HF}$ for cherts. While limestones can be left in the acid until reaction ceases, cherts should not be left in acid for more than 24 hours (Pessagno \& Newport 1972).

The acid residue or disintegrated host-rock is then sieved and dried. The most accessible nylon mesh-sieves are those usually used for silk-screen prints. A set of mini-sieves can be produced by using regular film boxes, where the bottom is cut out and the nylon sieve is welded to it with a hotplate (or an old electric iron). We used mesh sizes of $0.03 \mathrm{~mm}$, $0.05 \mathrm{~mm}, 0.08 \mathrm{~mm}, \quad 0.1 \mathrm{~mm}, 0.25 \mathrm{~mm}$, and $0.5 \mathrm{~mm}$, which are all commercially available (Table 1).

2) The central part of our new method requires a thermoelectric cooler (Peltier module). Pel- tier modules were originally designed for air conditioners, hot cabinets and mini-refrigerators and have recently been used to cool integrated circuit chips. When connected to the operating voltage, one side of the module will become cold and the other warm. We have used a Peltier module from Conrad Electronic (Table 1) but several other companies also offer Peltier modules. The price ranges from ca. 10 to $50 €$ depending on the size and maximum heat output $(\Delta T)$. For our purpose even the cheapest and smallest Peltier module is sufficient (Table 1).

The Peltier module was mounted on a copper plate with a heat-conducting paste (Table 1) to reduce thermal transition between the Peltier module and the heatsink. The module is connected to an adjustable DC power supply unit (see Table 1 for specifications). To enhance the contrast for optical observations, a small piece of black self-adhesive foil is glued to the center of the Peltier module.

A single droplet of water is then placed on the center of the Peltier module (Fig. 1). To reduce lime deposits and the surface tension of water we used distilled water with the addition of a small amount of detergent (regular dish-washer). The droplet should be as small as possible, that is, not much larger than the 


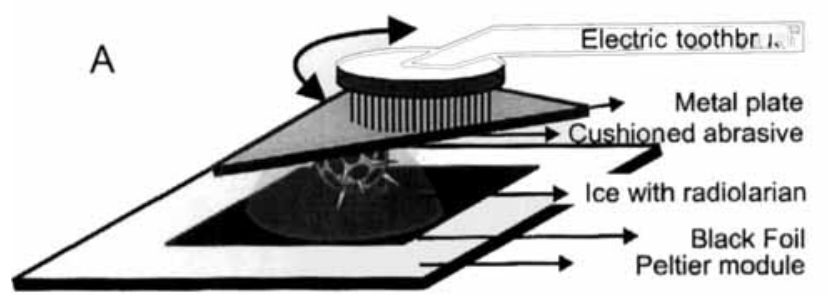

B

Peltier module

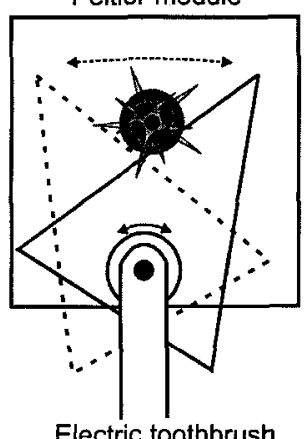

Fig. 1. Schematic illustration of the sectioning procedure. A. Oblique view showing modified electric toothbrush sectioning a radiolarian frozen in a droplet of water. B. Plan view showing oscillating motion of the sectioning device permitting continuous observation of the grinding process.

radiolarian test. Surplus water can be removed with a small pipette.

The radiolarian specimen is then placed into the droplet using a very fine brush, or even better, a single hair. We used a single untrimmed nose hair glued with wax to a round wooden stick (diameter $8 \mathrm{~mm}$ ). Nose hair is ideal for the picking of tiny fragile objects because its tip is very small (around $3 \mu \mathrm{m}$ ) and stable.

After the specimen is in place, the Peltier module is switched on (cooling mode) and the droplet containing the specimen is snapfrozen at $-20^{\circ} \mathrm{C}$.

3) Sectioning of the radiolarian specimen can be done with a variety of devices, but we achieved the best results with a modified electric tooth brush (Fig. 1). The bristles of the brush were cut as short as possible. The new surface of the brush was polished with a nailfile and a thin, triangular piece of sheet metal or plastic was attached with superglue. Emery cloths (cushioned abrasive) were then sized to the triangular plate and attached with doublesided adhesive tape. Several emery sets are commercially available but only emery cloths with a fine granulation are appropriate for radiolarian sectioning. We use the KR-70 kit from Micro-Mesh (Table 1) with a $1500-1800$ grade. The triangular form of the newly constructed orbital finishing sander al- lows a continuous viewing of the grinding process, if the radiolarian is ground close to the acute corner of the triangle. Partially ground tests can be unfrozen, reoriented and refrozen several times. We used a binocular microscope at 50 times magnification to observe and control the abrasion depth. A camera documented the whole process (Fig. 2).

The specimen was usually transferred to its final destination when the center of the test or any other desired feature was reached. The Peltier module is switched off and after thawing of the ice, the wet radiolarian is picked with a fine brush and transferred into a mini-sieve (step 1). The mini-sieve is then briefly treated in an ultrasonic bath to remove grinding remains and internal sediment from the test. The radiolarian specimen must not be allowed to dry prior to ultrasonic treatment, because this leads to cementation of the grinding residue to the test. Ultrasonic cleaning should be as brief as possible to avoid destruction of delicate tests. The Peltier module needs to be cleaned with a napkin after every grinding procedure.

After ultrasonic cleaning, the mini-sieve containing the specimen is immersed in pure industrial alcohol to fully remove water from the radiolarian. The test is finally transferred to either an SEM target plate or mounted with Canada Balsam onto a slide for optical examination under high magnification. Both optical investigation and SEM analysis can yield high-resolution 3D images of radiolarian internal structures, ran-

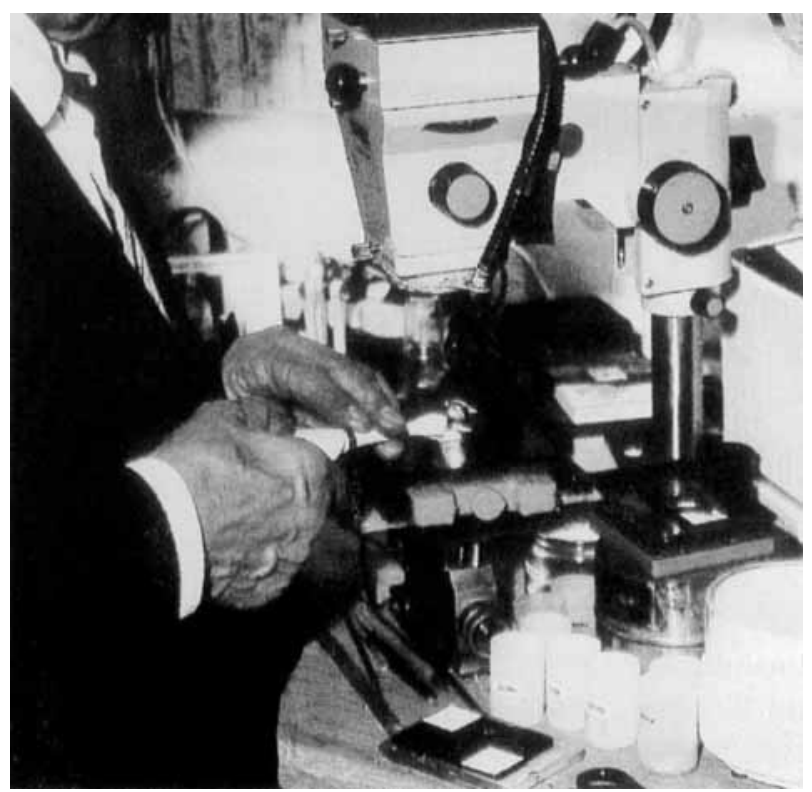

Fig. 2. Photograph of our work bench for the sectioning of radiolarians. The box contains the modified Peltier module. 


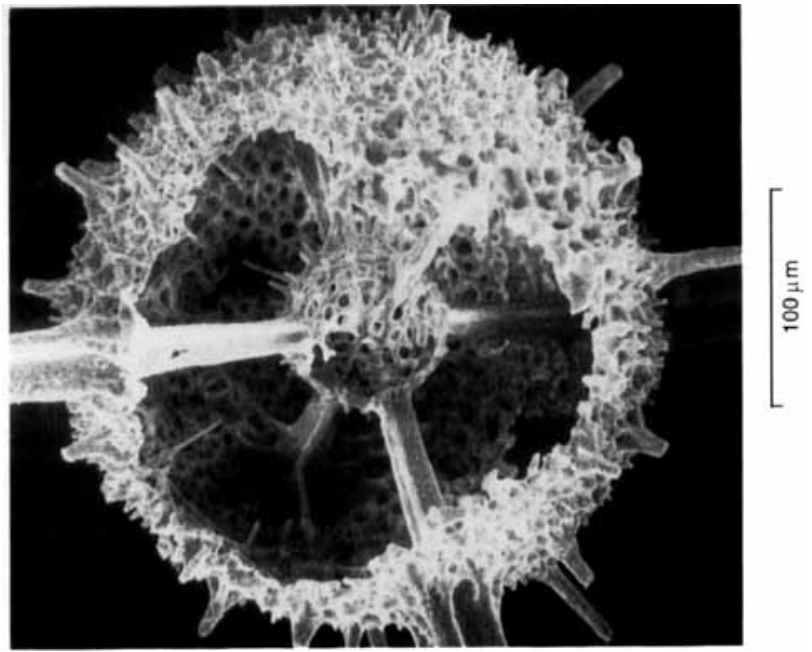

Fig. 3. Unnamed actinommid spumellarian with simple latticed medullary shell and spiny cortical shell. Ca. $280 \times$. Mörnsheim Formation near Mühlheim (early Tithonian). See Zügel (1997) for locality description.

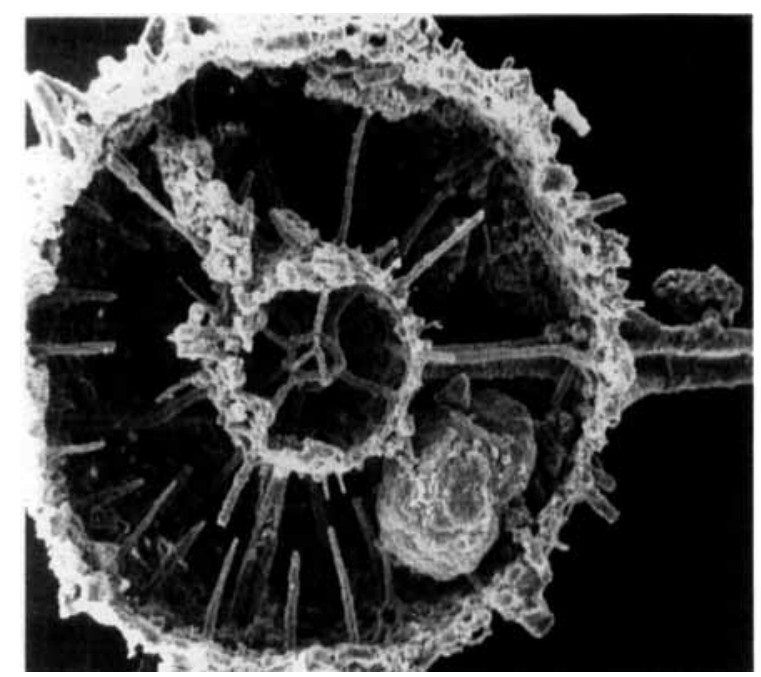

Fig. 4. Unnamed centrocubid entactinarian. This specimen would be mistaken for an actinommid spumellarian without the sectioning. Ca. $300 \times$. See Fig. 3 for origin of specimen.

ging from multiple concentric spherical shells (Fig. 3), to latticed microspheric shells (Figs 4-5), eight-spined initial spicules (Fig.6) and spiral shells (Fig. 7).

Very fragile tests can also be embedded in a thin layer of imbedding lacquer (e.g., PERTEX or a regular nail polish) instead of water. This method does not require a Peltier module. A particularly smooth surface is achieved if a little oil is added during grinding. The radiolarian can later only be investigated with an optical microscope because the lacquer cannot be removed without damaging the test.

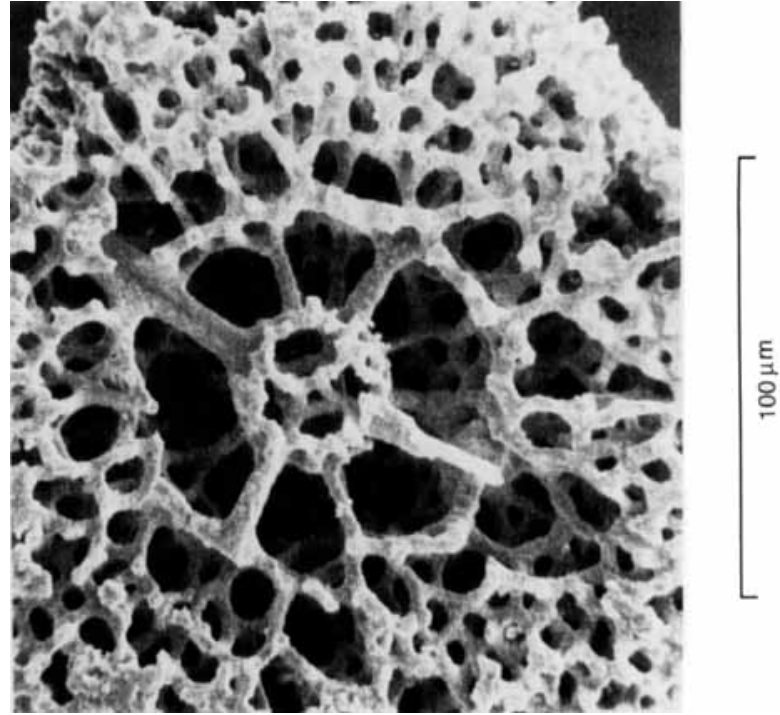

Fig. 5. Unnamed centrocubid entactinarian. Different genus than in Fig. 4, Ca. $500 \times$. See Fig. 3 for origin of specimen.

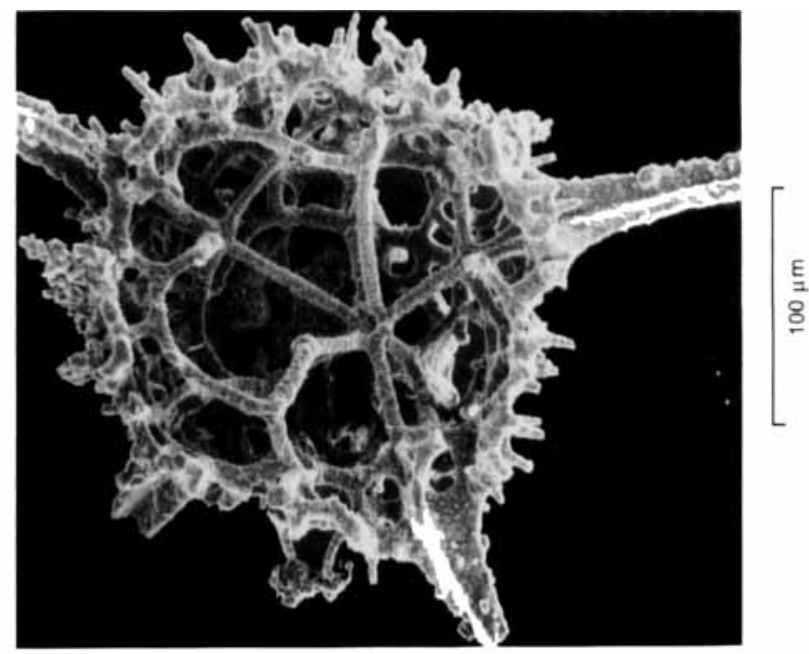

Fig. 6. Unnamed entactiniid entactinarian with an eight-spined initial spicule (Entactinia? sp.). Entactiniidae are typical Paleozoic radiolarians that were considered to be extinct since the Early Jurassic (De Wever et al. 2001). Ca. $300 \times$. See Fig. 3 for origin of specimen.

\section{Conclusion}

The new method is applicable to all kinds of microscopic particles. It is especially useful if the internal structure may yield important information. We have experimented with benthonic foraminifera and achieved excellent results. For the comparatively larger shells of foraminifera a slightly coarser sander kit than the KR-70 can be used. We recommend the DIAPAD 3M kit available from many stone tool retailers (Table 1). Because the study of foraminiferal internal structures usually does not require SEM observations, the new method may be a welcome replacement 


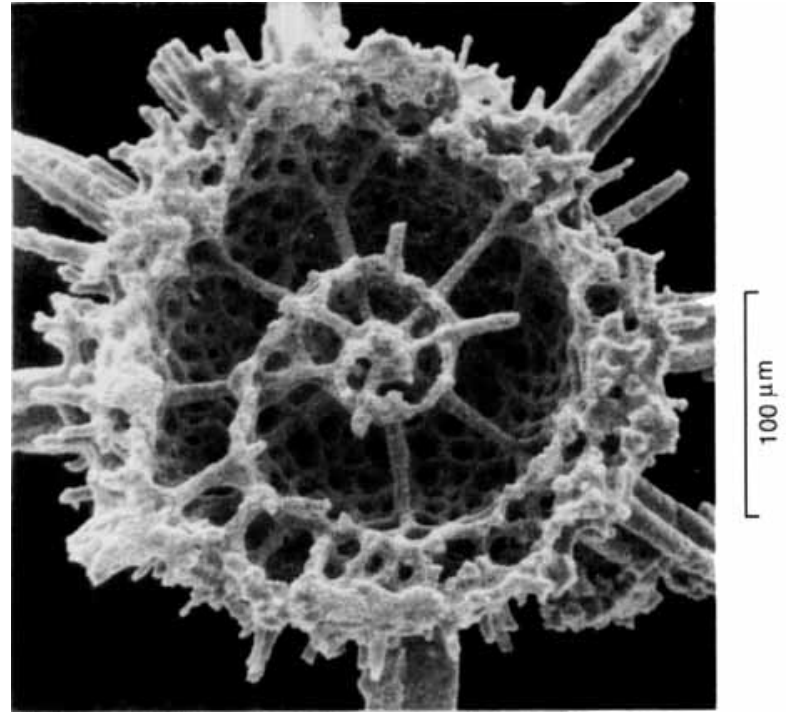

Fig. 7. Unnamed litheliid spumellarian (Lithelius? sp.) sectioned to the microsphere. Ca. $250 \times$. See Fig. 3 for origin of specimen.

for the traditional method of thin section analysis.

We especially hope that colleagues working on Mesozoic radiolarians will apply this new method and provide more details on the internal structure of new taxa in the future. Only after a taxonomic framework based on internal structures is established will the evolutionary history and ecological potential of radiolarians be fully realized.

\section{Acknowledgements}

We thank Peter Zügel for providing radiolarian material from the Solnhofen area (Germany). Many thanks also to Charlotte Stanek, who offered her technical knowledge and patience for this project. Paulian Dumitrica, David Lazarus, and Barry O'Connor are thanked for helpful comments on the manuscript.

\section{References}

Baumgartner, P. O. 1980. Late Jurassic Hagiastridae and Patulibracchiidae (Radiolaria) from the Argolis Peninsula Peloponnesus, Greece). - Micropaleontology 26: 274-322.

De Wever, P., Dumitrica, P., Caulet, J. P., Nigrini, C. \& Caridroit, M. 2001. Radiolarians in the sedimentary record. 533 pp., Gordon \& Breach Sc., London.

Dumitrica, P. 1983. Evolution of Mesozoic and Cenozoic Centrocubidae (Radiolaria). - Revue de Micropaléontologie 25 (4): $221-230$.

- 1985. Internal morphology of the Saturnalidae (Radiolaria): systematic and phylogenetic consequences. - Revue de Micropaléontologie 28 (3): 181-196.

- 1988. New families and subfamilies of Pyloniacea (Radiolaria). - Revue de Micropaléontologie 31 (3): 178-195.

- 1989. Internal skeletal structurs of the Superfamily Pyloniacea (Radiolaria), a basis of a new systematics. - Revista Española de Micropaleontología 21: 207-264.

- 1991. Cenozoic Pyloniacea (Radiolaria) with a five-gated microsphere. - Revue de Micropaléontologie 34 (1): 35-56.

- 1994. Pyloctostylus n. gen., a Cretaceous spumellarian radiolarian genus with initial spicule. - Revue de Micropaléontologie 37: 235-244.

Dumitrica, P. \& Carter, E. S. 1999. Family Kungalariidae, n. fam., new Mesozoic entactinarian Radiolaria with a nassellarian-type initial spicule. - Micropaleontology 45 (4): $418-428$.

Kozur, H. \& Mostler, H. 1982. Entactinaria subordo nov., a new radiolarian suborder. - Geologisch-Paläontologische Mitteilungen Innsbruck 11/12: 399-414.

Lazarus, D. 1994. An improved cover-slip holder for preparing microslides of randomly distributed particles. - Journal of Sedimentary Research A64: 686.

O'Connor, B. 1996. Confocal laser scanning microscopy: A new technique for investigating and illustrating fossil Radiolaria. - Micropaleontology 42 (4): 395-402.

Pessagno, E. A. \& Newport, R. L. 1972. A technique for extracting Radiolaria from radiolarian cherts. - Micropaleontology 18 (2): 231-234.

Takemura, A. 1986. Classification of Jurassic Nasselarians (Radiolaria). - Palaeontographica Abt. A 195: 29-74.

Won, M.-Z. 1997. The proposed new radiolarian subfamily Retentactiniinae (Entactiniidae) from the late Devonian (Frasnian) Gogo Formation, Australia. - Micropaleontology 43 (4): 371-418.

Zügel, P. 1997. Discovery of a radiolarian fauna from the Tithonian of the Solnhofen area (Southern Franconian Alb, southern Germany). - Paläontologische Zeitschrift 71: $37-49$. 